Military Technical College

Kobry El-Kobbah, Cairo, Egypt.

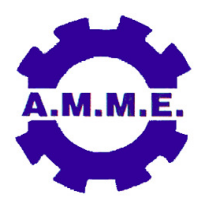

\title{
EXPERIMENTALLY INVESTIGATING THE BALLISTIC PROPERTIES OF THE POLYMER-MATRIXED LAYERED AND FIBER- REINFORCED COMPOSITE MATERIALS
}

\author{
H. Yilmaz ${ }^{1}$, F. Bedir ${ }^{1}$ and U. Elmas ${ }^{2}$
}

\begin{abstract}
In this study, the ballistic properties of the hybrid armor samples that have different number of layers of para-aramid material Kevlar 129, polyethylene material SB21 and woven material E-glass, produced by hand lay-up and hand-pressing with using epoxy resin matrix against $9 \mathrm{~mm}$ bullet, were investigated experimentally. In the tests the protection levels are applied per NIJ 0101.04 standards (National Institute of Justice (NIJ) Level III A, the approved U.S.A. Ballistic Standard). Results show that the area of the delamination is important to quantify the ballistic properties.
\end{abstract}

\section{KEYWORDS}

High velocity impact, polymer matrix composite, ballistic properties.

1 Suleyman Demirel Universitesi Makina Mühendisliği Bölümü, 32260 Isparta-Turkey.

2 The Scientific and Technological Research Council of Turkey (TUBITAK), 06100 Ankara-Turkey. Corresponding author: Umran Elmas, umran.elmas@tubitak.gov.tr, Phone: +(90) 312-468-53-00 (Extension: 4572) 


\section{INTRODUCTION}

By the reasons of better thermal, acoustic and insulation properties, mechanical properties have also sufficient corrosion resistance, higher rates in strength-toweight and in module-to-weight ratios with good design properties as well as by easily-applied production techniques. Composite materials have wide range application areas in defense-related applications. The more, armors used in the individual self-defense purposes are mostly produced by polymer-matrix composites because of their ballistic properties [1].

Composite armor is absorbing the kinetic energy of a bullet by distributing and spreading in a short time without piercing and having less effect of the impact through target. So it is not enough to design an armor only against to piercing but it is also necessary to study the instant deformation occurring at the back face of it [2]. Important experimental studies are available for using different configurations of composite structures that are produced for individual defense purposes or damping the kinetic energy of a bullet or a particle as well as studying elastic and plastic debris occurring at the back face after the ballistic impact. The damage and depth with the type of impact energy are important in terms of the behaviour of the layered composite materials against low and high velocity impact [3].

There are many experimental and numerical studies for Kevlar 29 as an armor material in investigating damage types and mechanisms, back face trauma and piercing. It has been concluded that the results are so close to each other [4]. Also polyethylene hard ballistic material HB25, different types and layers of carbon and glass fiber containing composite structures have been studied numerically and experimentally at different temperatures [5]. Samples of orthogonally oriented Kevlar 29 layers and E-glass layers, manufactured by vinylester resin matrix were tested to specify ballistic properties with $5 \mathrm{~mm}$ diameter steel ball projectile at the speed range between $600-1050 \mathrm{~m} / \mathrm{sec}$. It has been noticed that the fibers at $Z$ axis absorbed much more energy for both type samples but Kevlar 29 samples absorbed much more energy than E-glass [6]. Garcia-Castillo et all [7] investigated the ballistic behaviour of polymer matrixed E-glass samples with the shots at the range of 200$510 \mathrm{~m} / \mathrm{sec}$ by steel ball having same diameter to report the changes in geometry and density rates. The test results showed that increasing rates of sample dimension and density cause the increase of ballistic limit. Independently from these changes fiber breakage under ballistic limit and cone formation above ballistic limit are the main energy absorption mechanisms.

In this study, it has been noticed that mono-phased E-glass or para-aramid and monolithic two phased para-aramid woven fabric structures are usually preferred to provide protection against high-speed impacts. High density polyethylene materials are rarely used as single phase for monolithic type studies. No studies related to the ballistic resistance of hybrid composite structures with mixture of woven fabric and polyethylene materials have been reported yet. The present work is concerning with constructing and testing of the hybrid composite structures, which are capable of defeating $9 \mathrm{~mm}$ projectiles which is the most common threat in civil application. 


\section{EXPERIMENTAL WORK}

\section{Composite Hybrid Panels}

The amount of resin in matrix is one of the most important factor affecting the mechanical properties of the composites. There are two methods to produce the composite depending on the applying resin, pregreg and resin reinforced method such as hand lay-up. Hand lay-up is the most common method to produce resin based composite. On the other hand pregreg is a standard manufacturing method using to commercially produce the polymer composites of which resin is penetrated into fiber structure during the processes. A production method to be selected affects the physical properties of the composite depending on reinforcing material (fiber), matrix material (resin), part geometry [8].

In this paper, armor panels were manufactured by hand lay-up method and by impregnating thermoset epoxy resin between the layers under hand-pressing. Eglass layers were placed between plane waved para-aramid Kevlar 129 and crossplied polyethylene material SB21 layers. The pressing at averaging 5-7 bar and then the curing process at $130{ }^{\circ} \mathrm{C}$ in 4 hours were performed for each sample (Fig.1). Total of 12 samples were prepared. Kevlar 129 and SB21 used in the experimental studies were commercially procured. The other type of fiber woven material of $E$ glass and epoxy resin were supplied from Izoreel Company in Izmir, Turkey. Projectile velocities and back face signatures were measured by ballistic tests. It was aimed to investigate the ballistic properties of samples that are 2 and 3 phased manufactured with different ballistic materials in different configuration. It was observed that shoting through the Kevlar 129 side caused more energy absorption of the 3 phased systems respect to SB21 side.

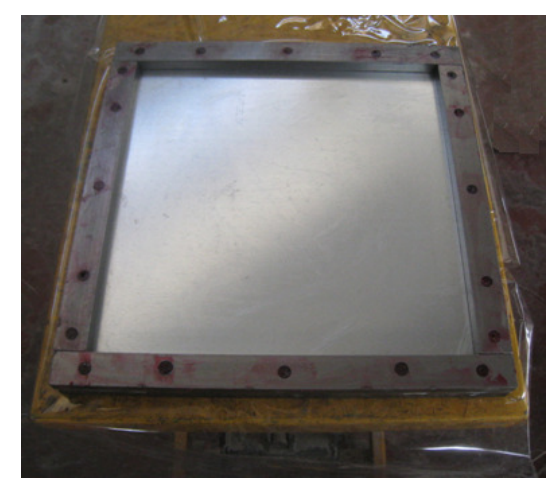

Fig.1. Preparation for molding process.

The areal density and the thickness values of the prepared samples for E-glass fiber, Kevlar 129 and SB21 were $270 \mathrm{~g} / \mathrm{m}^{2}, 280 \mathrm{~g} / \mathrm{m}^{2}$ and $150 \mathrm{~g} / \mathrm{m}^{2}$ in density and 0,22 $\mathrm{mm}, 0,25 \mathrm{~mm}$ and $0,19 \mathrm{~mm}$ in thickness respectively. $1,1 \mathrm{~g} / \mathrm{cm}^{3}$ density-having Hexion Epikote 828 epoxy resin was used as a matrix material for the composite samples. The dimensions of the prepared samples are $340 \times 340 \mathrm{~mm} \times \mathrm{mm}$. The layer arrangements and the number of layers were given in detail in Table 1. 
Table 1. Configurations of the constructed composite armors.

\begin{tabular}{|c|c|c|c|c|c|c|c|c|}
\hline $\begin{array}{l}\text { The c } \\
\text { numb }\end{array}$ & $\begin{array}{l}\text { nfiguration } \\
\text { r of layers }\end{array}$ & comp & 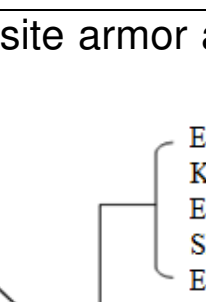 & $\begin{array}{l}\text { nd the } \\
\text { lass } \\
\text { lar } 129 \\
\text { lass } \\
21 \\
\text { lass }\end{array}$ & $\begin{array}{l}\text { Composite } \\
\text { Sample's } \\
\text { Weight, g }\end{array}$ & $\begin{array}{l}\text { Sample's } \\
\text { Thickness }\end{array}$ & $\begin{array}{c}\% \\
\text { Volumetric } \\
\text { Amount of } \\
\text { Fibers }\end{array}$ & $\begin{array}{c}\% \\
\text { Volumetric } \\
\text { Amount of } \\
\text { Matrix }\end{array}$ \\
\hline $\begin{array}{c}\text { E- } \\
\text { glass }\end{array}$ & Kevlar129 & $\begin{array}{c}\text { E- } \\
\text { glass }\end{array}$ & SB21 & $\begin{array}{c}\text { E- } \\
\text { glass }\end{array}$ & & & & \\
\hline 10 & 10 & 10 & 10 & 10 & 1700 & 10,5 & 74,75 & 25,15 \\
\hline 10 & 15 & 10 & 15 & 10 & 1950 & 12 & 78,75 & 21,25 \\
\hline 10 & 20 & 10 & 20 & 10 & 2550 & 14 & 79,06 & 20,94 \\
\hline & & & & $\begin{array}{l}\text { glass } \\
21 \\
\text { glass } \\
\text { evlar } 129 \\
\text { glass }\end{array}$ & & & & \\
\hline $\begin{array}{c}\text { E- } \\
\text { glass }\end{array}$ & SB21 & $\begin{array}{c}\text { E- } \\
\text { glass }\end{array}$ & Kevlar129 & $\begin{array}{c}\text { E- } \\
\text { glass }\end{array}$ & & & & \\
\hline 10 & 10 & 10 & 10 & 10 & 1700 & 10,5 & 74,75 & 25,15 \\
\hline 10 & 15 & 10 & 15 & 10 & 1950 & 12 & 78,75 & 21,25 \\
\hline 10 & 20 & 10 & 20 & 10 & 2550 & 14 & 79,06 & 20,94 \\
\hline
\end{tabular}

After measuring back face signature of the 6 samples that have 3 phase configuration by BOSCH PCL10 laser level meter, they were cut on the shot points and cross section surfaces inspected and photographed by NIKON D80 digital camera (1:2) with $72 \mathrm{~mm}$ macro lens.

\section{Ballistic Test Setup}

Ballistic tests have been realized to NIJ 0101.04 standard (National Institute of Justice (NIJ) Level III A, the approved U.S.A. Ballistic Standard) for application in multi-layered panels designed to defeat high-velocity ballistic impacts of various type of projectiles. The shots impact perpendicularly to the target and this is provided by fixed barrel and laser pointing device. The speed of bullets determined by using Oehler Research Model ORM 55 accelerometer and double electrical curtains located at $1 \mathrm{~m}$ away from the accelerometer. The schematic view of the shot test system is given in Fig.2. For each sample, 6 shots have been performed.

The glass paste was placed to represent the armor as target and the rear part as human skin at the ballistic tests. For this purpose the glass paste at $22^{\circ} \mathrm{C}\left(15^{\circ} \mathrm{C}<\mathrm{T}\right.$ $<30^{\circ} \mathrm{C}$ ) for 3 hours was kept at the conditioning cabinet and then it is compressed in order to get rid of the gaps inside completely. The thickness of the paste prepared was $10 \mathrm{~cm}$ and the method used for determining the suitability of the ballistic tests 

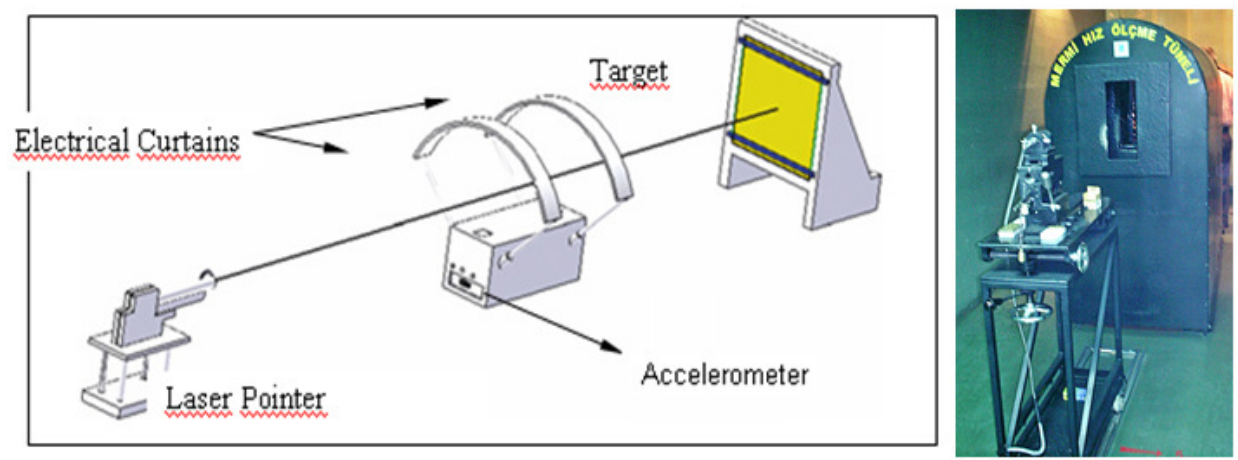

Fig.2. Schematic view of the shoting test system.

was to vertically drop the cylindrical steel part in $44,5 \pm 0,5$ diameter and in $1000 \pm 10 \mathrm{~g}$ in such a way that its hemispherical tip is towards the ground from $200 \pm 2 \mathrm{~cm}$ height. As a result of the drop, the resulting debris on the surface of glass-paste should be $25 \pm 3 \mathrm{~mm}$. In that way three drop tests were performed and the paste conditioning was provided per the standards (NIJ0101.04). The schematic representation of the conditioned glass material and the target material placed in the fixing apparatus was given in Fig.3.
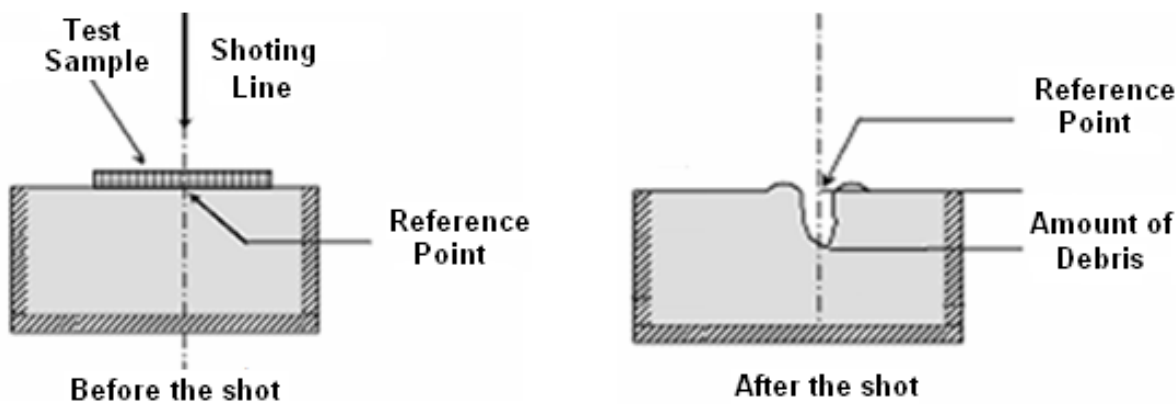

Fig.3. Conditioned filler material placed at the rear part of the targeted armor material simulates the human skin during the ballistic tests.

Each armor sample clamped on the paste surface before each shoting set. Shots have been fired from $5 \mathrm{~m}$. For each shot bullet speed has been changed by setting the amount of gun powder in each shell. For each shot deformation and back face signature measured and recorded.

In the ballistic tests $9 \mathrm{~mm}$ bullets consisting of brass jacket and copper core were employed. The technical specifications of the $9 \mathrm{~mm}$-bullets were given in Table 2 . Fig.4 shows the structure and the core measurements too. 
Table 2. The Standard Characteristics of $9 \mathrm{~mm}$-Bullet.

\begin{tabular}{|l|c|}
\hline Core diameter $(\mathrm{mm})$ & 9,08 \\
\hline Core Mass $(\mathrm{g})$ & 7,43 \\
\hline Cartridge Case Mass $(\mathrm{g})$ & 3,80 \\
\hline Core length $(\mathrm{mm})$ & 15,70 \\
\hline $\begin{array}{l}\text { Amount of standard } \\
\text { gunpowder }(\mathrm{g})\end{array}$ & $0,41 \pm 0,005$ \\
\hline
\end{tabular}

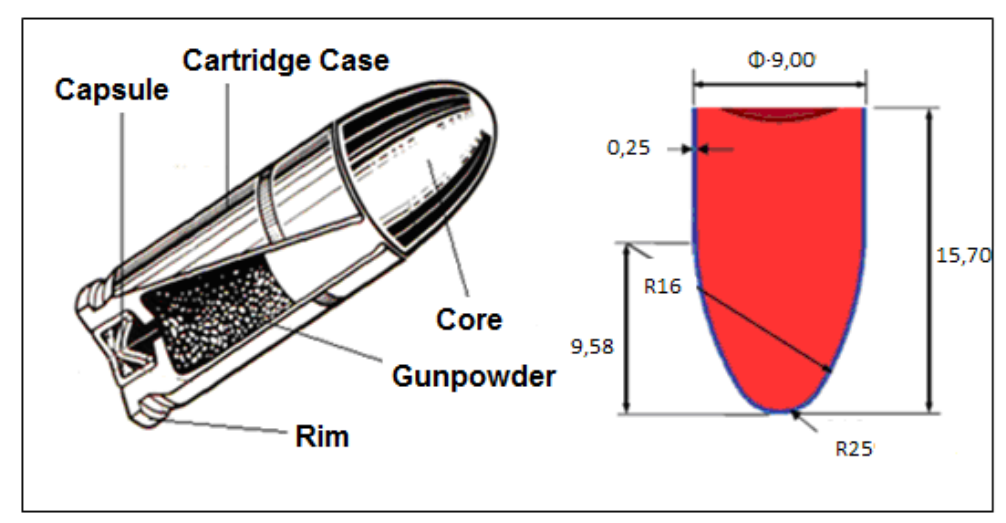

Fig.4. $9 \mathrm{~mm}$-bullet used for shoting tests.

\section{RESULTS AND DISCUSIONS}

\section{The Samples of Fiber-Layered E- Glass / Kevlar 129 / SB21 Materials with Epoxy Resin Matrix}

Figure 5 shows the sample of epoxy-resin-matrix [[(E-glass $)_{10}+(\text { Kevlar 129 })_{10}+(\mathrm{E}-$ glass $\left.\left.)_{10}+(\mathrm{SB} 21)_{10}+(\mathrm{E} \text { - glass })_{10}\right]_{50}\right]$ material after shooting tests. Velocity and kinetic energy of the bullets, delamination diameter and back face signature values of armor panel for each shot are given in Table 3.
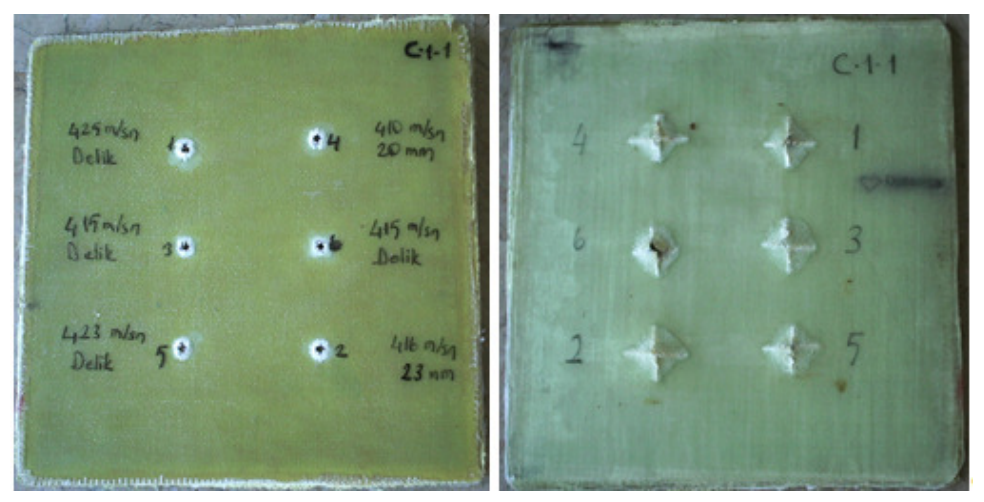

Fig.5. The sample of exopy-resin-reinforced [[(E- glass $)_{10}+(\text { Kevlar 129 })_{10}+(\mathrm{E}-$ glass $\left.)_{10}+\left(\mathrm{SB} 21_{10}+(\mathrm{E} \text { - glass })_{10}\right]_{50}\right]$ material by which the shot tests were performed. 
Table 3. Ballistic test results for the sample of epoxy-resin-having [[(E-Glass) $10+$ $\left.\left.(\text { Kevlar 129 })_{10}+(\text { E-Glass })_{10}+(\text { SB21 })_{10}+(\text { E-Glass })_{10}\right]_{50}\right]$ material.

\begin{tabular}{|c|c|c|c|c|c|c|}
\hline $\begin{array}{c}\text { Shot } \\
\text { No }\end{array}$ & $\begin{array}{c}\mathbf{V}_{\mathbf{m}} \\
(\mathbf{m} / \mathbf{s e c})\end{array}$ & $\mathbf{E}_{\mathrm{K}}(\mathbf{N} . \mathbf{m})$ & $\begin{array}{c}\text { Debris } \\
\text { Depth } \\
\mathbf{( m m})\end{array}$ & $\begin{array}{c}\text { Back Face } \\
\text { Signature / } \\
\text { Delamination } \\
\text { Height (mm) }\end{array}$ & $\begin{array}{c}\text { Back Face } \\
\text { Signature / } \\
\text { Delamination } \\
\text { Diameter (mm) }\end{array}$ & Results \\
\hline 1 & 425 & 671,021 & - & 7,32 & 40 & Perforation \\
\hline 2 & 416 & 642,903 & 23 & 5,44 & 45 & NIJ III-A \\
\hline 3 & 415 & 639,815 & - & 5,65 & 40 & Perforation \\
\hline 4 & 410 & 624,491 & 20 & 5,40 & 45 & NIJ III-A \\
\hline 5 & 423 & 664,721 & - & 6,84 & 40 & Perforation \\
\hline 6 & 415 & 639,815 & - & 5,57 & 40 & Perforation \\
\hline
\end{tabular}

All shots, except the 2nd and 4th, perforate the armor panel. The main reasons of this, regional insufficient resin penetration during hand lay-up application or pressure differences while hand pressing are the causes perforation of the armor panel.

The photos of the front and back surface of the armor panel were given in Fig.5. Impact points can be seen at the front face. The shots which were resulted by perforation can be seen from the back face of the target (shots 1, 3, 5 and 6).

It can be seen that the delamination is perpendicular to each other for each shot on the back face of the target. For the shots which resulted by perforation, delamination occur on the same arrangement and they have equal lengths $(40 \mathrm{~mm})$ for both horizontal and vertical axis. For the 2nd and 4th shots which are not resulted by perforation, the length of delamination in horizontal axis longer than the other shots which are resulted by perforation because of more kinetic energy absorption. The length of delamination at the horizontal axis are about $45 \mathrm{~mm}$ in length for both shots of 2 and 4.

SB21 layer is so close to the perforation for the shots 2 and 4 . The shot no.2 whose bullet speed is $416 \mathrm{~m} / \mathrm{sec}$ is particularly so close to the ballistic limit. The average speed value for all of the shots including those where the perforation is noticed is $417 \mathrm{~m} / \mathrm{sec}$. The corresponding average back face signature / delamination height value is $6 \mathrm{~mm}$. The average speed for the shots where the perforation is not noticed is $413 \mathrm{~m} / \mathrm{sec}$ and corresponding average back face signature / delamination height value is $5,42 \mathrm{~mm}$.

The cross sections of the shooting points belong to the sample was given in Fig.6. The shot 1 is the highest speed among all of the shots and the perforation occurred at this shot. Even though the perforation is observed, the core is completely shattered and one part of it is remained in the SB21 layer. The fibers of the E-glass and Kevlar 129 layers have sudden breakage in the area where the core hits the target. The core coating between Kevlar 129 and E-glass layers was crushed. Fiber breakage in SB21 and in E-glass layers, which is the lowermost layer as well as delamination in the perforation area were observed. 
Figure 6 also shows the cross section images after the shot no.2 is completed. Sudden fiber breakage in the E-glass and Kevlar 129 layers occur in the area where the core hits the target.

In this shot not occurring the perforation in the composite, the core coating is shattered in the E-glass layer after passing the Kevlar 129 layer.

Beside the threat had been blocked, deformation was occurred between SB21 layer and former E-glass layer. The reasons of this, it was though that deformation were occurred as depending on the manufacturing methods of armor, it means, less resin absorption by SB21 material and its effect on the ballistic impact.

Additionally with delamination effect, the fiber breakage was occurred at the latest Eglass layer under impact shock.

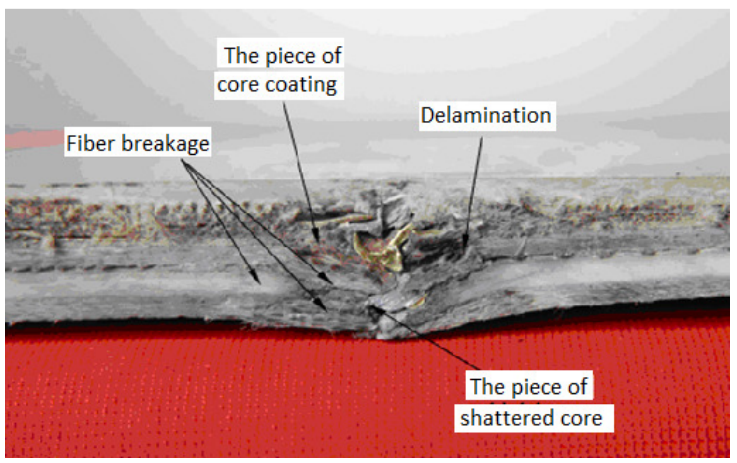

(a)

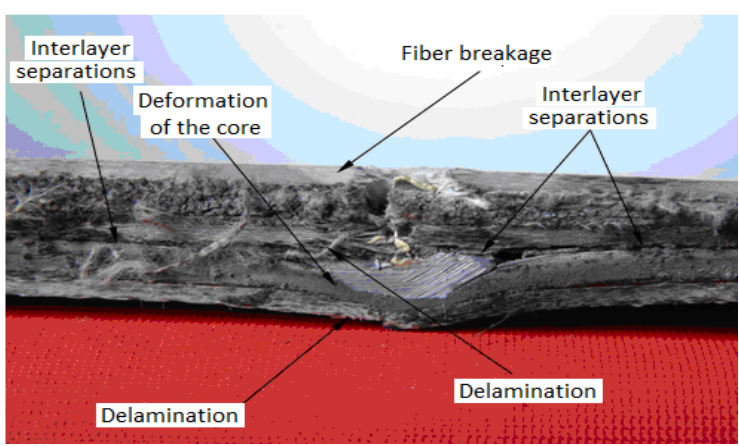

(c)

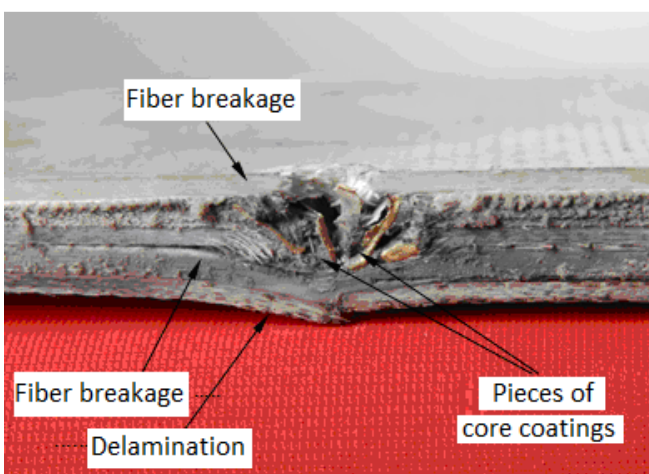

(b)

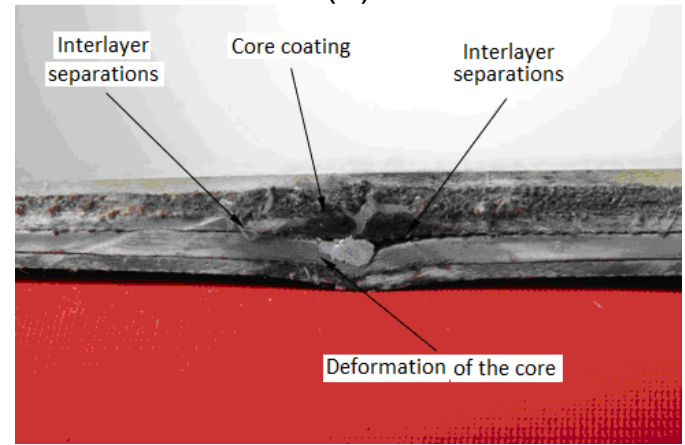

(d)

Fig.6. (a), (b): The cross-sectional images of the material for the shot no.1 (c), (d): The cross-sectional images of the material for the shot no. 2.

\section{The Samples of Fiber-Reinforced Epoxy Resin-Matrixed Material of E-glass / SB21 / Kevlar 129}

Figure 7 shows the sample of epoxy-resin-matrix $\left[\left[(E-g l a s s)_{10}+(\mathrm{SB} 21)_{20}+(\mathrm{E}-\right.\right.$ glass $\left.\left.)_{10}+(\text { Kevlar 129 })_{20}+(\text { E-glass })_{10}\right]_{70}\right]$ material after shutting tests. It was summarized in Table 4 that gives the bullet speeds, kinetic energy, back face signature / delamination diameters and the debris values. 

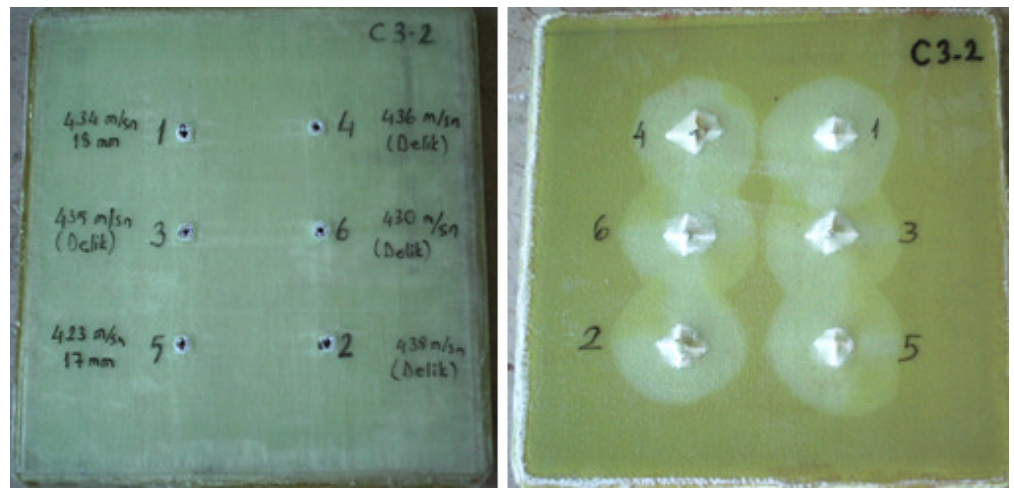

Fig.7. The sample of exopy-resin-reinforced [[(E-glass $)_{10}+(\mathrm{SB} 21)_{20}+(\text { E-glass })_{10}+$ $\left.\left.(\text { Kevlar 129 })_{20}+(\text { E-glass })_{10}\right]_{70}\right]$ material after the shot tests.

Table 4. The shot tests' results for the samples of E-glass (10x3 layers)/SB21 (20 layers)/Kevlar 129 (20 layers).

\begin{tabular}{|c|c|c|c|c|c|c|}
\hline $\begin{array}{c}\text { Shot } \\
\text { No }\end{array}$ & $\begin{array}{c}\mathbf{V}_{\mathbf{m}} \\
(\mathbf{m} / \mathbf{s e c})\end{array}$ & $\mathbf{E}_{\mathbf{K}}(\mathbf{N m})$ & $\begin{array}{c}\text { Debris } \\
\text { Depth } \\
(\mathbf{m m})\end{array}$ & $\begin{array}{c}\text { Back Face } \\
\text { Signature / } \\
\text { Delamination } \\
\text { Height (mm) }\end{array}$ & $\begin{array}{c}\text { Back Face } \\
\text { Signature / } \\
\text { Delamination } \\
\text { Diameter (mm) }\end{array}$ & Results \\
\hline 1 & 434 & 699,742 & 18 & 5,68 & 31 & NIJ III-A \\
\hline 2 & 438 & 712,700 & - & 7,62 & 37 & Perforation \\
\hline 3 & 435 & 702,970 & - & 6,68 & 37 & Perforation \\
\hline 4 & 436 & 706,206 & - & 5,83 & 37 & Perforation \\
\hline 5 & 423 & 664,721 & 17 & 5,25 & 31 & NIJ III-A \\
\hline 6 & 430 & 686,903 & - & 6,76 & 37 & Perforation \\
\hline
\end{tabular}

Considering all shots, the perforation was generally occurred but not only at the 1st and 5th shots. The reason of this, it is though that SB21 layers had not been provided the sufficient energy absorption. By referring to the experimental results, SB21 is generally used as a support element in the ballistic structures because of fact that its stretching ability is higher in the direction of the material thickness.

When analyzing the rear surface of the sample after the shots, penetration points can be seen at the front face of target. They are perpendicular to each other and they have lengths about $37 \mathrm{~mm}$ and about $30 \mathrm{~mm}$ for horizontal and vertical axis respectively. For the shots no:1 and no.5, which were not seen the perforation, the length of delamination are same in horizontal axis but about $31 \mathrm{~mm}$ in horizontal axis. Additionally there is delamination whose diameter is the same as those deformations which are centered at these points.

It can also be seen uneven, discolourated areas surrounding the delamination. The diameter of these areas for all shots are about $93 \mathrm{~mm}$. The average speed value for all of the shots including those where the perforation is not noticed is $432,67 \mathrm{~m} / \mathrm{sec}$. The corresponding average back face signature / delamination height value is 6,3 $\mathrm{mm}$. The average speed value for the shots where the perforation is not noticed is 
$428,50 \mathrm{~m} / \mathrm{sec}$ and the corresponding average back face signature / delamination height value is $5,46 \mathrm{~mm}$.

The cross sections of the shooting points for the sample are given in Fig.8. For the shot 1, the shattered core has a wide distribution in between SB21 layer and the back surface of the E-glass layer. The threat is blocked but deformation is observed between SB21 layer and former E-glass layer because of less resin absorption of SB21.

Occurring in the fiber breakage form the perforation occurred at the shot 2 of which speed was the highest in test.

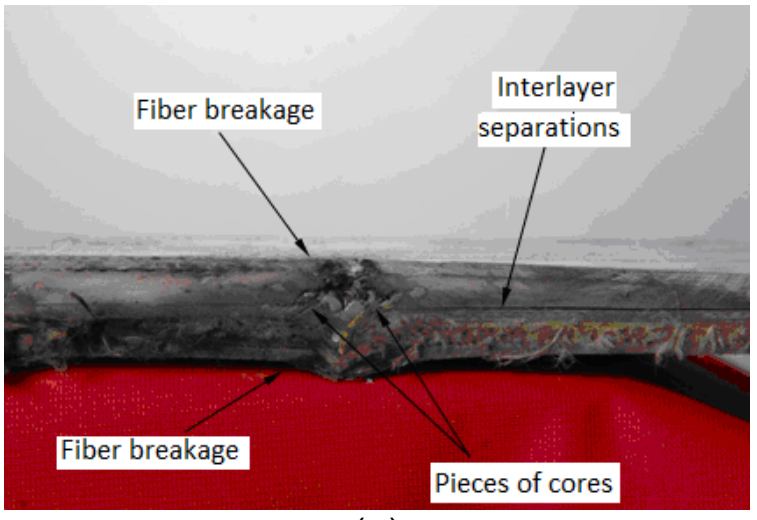

(a)

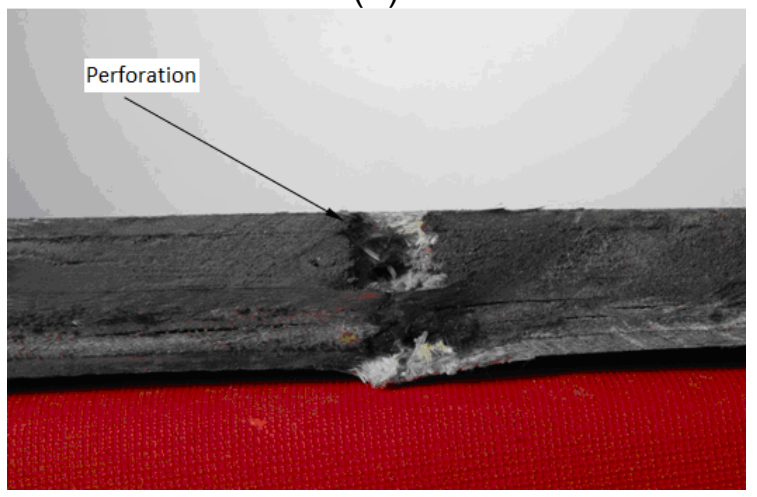

(c)

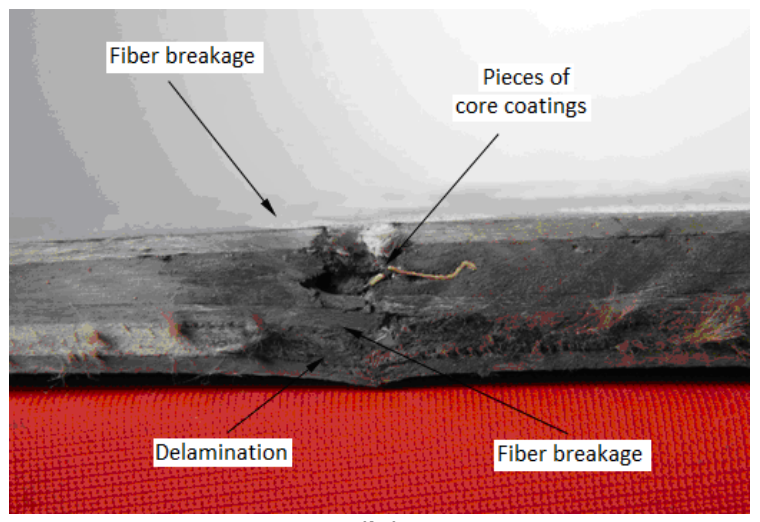

(b)

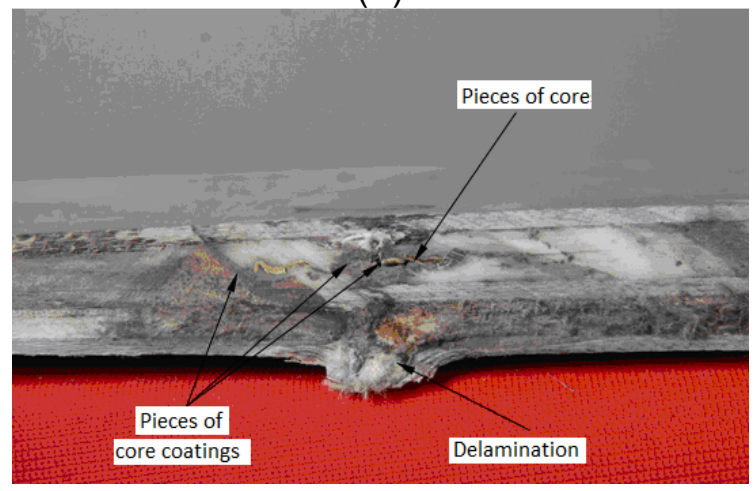

(d)

Fig.8. (a), (b): The cross-sectional images of the material for shot no.1 (c), (d): The cross-sectional images of the material for shot no.2

\section{Discussions}

The epoxy resin is used in the matrix composite for the test samples. Polymer matrix composites are generally brittle and they absorb the energy in the elastic region only. In all of the shot tests the primary fibers has breakage as long as they have reached their elongation value under the transverse impact. The fibers close to the impact point have lower elastic properties in the penetration direction. Therefore the stresses are very important when the load is applied. The type of ballistic damages may differ according to the structural properties of the test samples, the geometry, the speed and the mass of the bullet [9-11]. 
After shoting tests, failure occurred in the composite sample such as delamination, fiber breakage, interlayer separation, back face signature and matrix cracking. Impact effect of the bullet presses the part of the sample and forms a cavity in which deformation occurs through the thickness of the material. During the bullet penetrating into the composite structure, normal stresses occurring between the layers cause the forming and the growing the delamination [12-14].

The sufficient bonding cannot be established between the layers because the hand lay-up method doesn't offer sufficient resin absorption. Additionally the absorption of resin is low at fiber structure of polyethylene SB21. Moreover reduced material thickness in the direction of the bullet at the back side of the sample, where the perforation is not seen, results in lowering the reaction resistance against the bullet. As a result of these factors, the effect of remaining kinetic energy of the bullet causes interlayer separation and the delamination at the back side of the layer [15].

Turkish Military Forces made some studies on Kevlar aramid composites without using epoxy resin, which are provided NIJ 2A level using gas-guns. So it became very important in this study to see how the resin effect the composite properties and damages between layers after shoting for civil applications, such as civil vehicle, civil patrol containers etc.

\section{CONCLUSIONS}

The experimental studies were carried out to obtain the ballistic properties of the polymer-matrix composite. The composite structure were composed of SB21, E glass and Kevlar 129 fibers, produced by the hand lay-up and the hand-pressing methods. In the tests the protection levels are applied per NIJ 0101.04 standards for $9 \mathrm{~mm}$-diameter bullet which is the most common threat in civil application. Experimental results show that an important factor occurring perforation is to be insufficient resin penetration between layers during the hand lay-up applications.

\section{REFERENCES}

[1] Tarakçıŏlu, I., Gülümser, T., Başal, G., Duran, D., Ilgaz, S. Mecit, D., 2007. Technical textiles and applications (Part 1), Tekstil ve Konfeksiyon, v.2, pp.7982.

[2] lannucci, L., Pope, D., 2011. High velocity impact and armor design. Express Polymer Letters Vol.5, 262-272.

[3] Ceyhun, V., Turan, M., 2003. Tabakalı kompozit malzemelerin darbe davranışı. Ege Üniversitesi, Mühendislik Fakültesi, Makine Mühendisliği Bölümü, M.M.O. Mühendis ve Makine, Cilt 44, Sayı 516.

[4] Da Silva, JR. J.E.L., Paclornik, S., d'Almeida, J.R.M., 2005. Evaluation of the effect of the ballistic damaged area on the residual impact strength and tensile stiffness of glass-fabric composite material. Elsevier Composite Structures 64, 123-127. 
[5] Project number: 106M004, Project title: Hafif silahlara karşı zırh yapımında kullanılan polimer matrisli kompozitlerlin balistik özelliklerinin incelenmesi, funded by TUBITAK (The Scientific and Technological Research Council of Turkey).

[6] Yu Y.M., Wang X.J., Lim C.W., 2009. Ballistic impact of 3D orthogonal woven composite by a spherical bullet: experimental study and numerical simulation. International Journal of Enginnering and Applied Sciences Vol 1, 1-18.

[7] Garcia-Castillo S.K., Sánchez-Sáez, S., Barbero, E., 2012. Nondimensional analysis of ballistic impact on thin woven laminate plates. Elsevier International Journal of Impact Engineering 39, 8-15.

[8] Bhatnagar, A., 2006. Lightweight ballistic composites. ABD-CRC Press, Woodhead Publishing Ltd., 1st edition, 429, Cambridge.

[9] Patts, H.M., 2000, Ballistic impact damage and penetration mechanics of fiber reinforced composite laminates. The Pennsylvania State University Engineering Science\&Mechanis, Doktor of Philosophy, 335, Pennsylvania.

[10] Sheikh, A.H., Bull, P.H., Kepler, J.A., 2009. Behaviour of multiple composite plates subjected to ballistic impact. Elsevier Comp. Sciene and Thec. 69, 704710.

[11] Wambua, P., Vangrimde, B., Lomov, S., Verposet, I., 2007. The response of natural fibre composites to ballistic impact by fragment simulating projectiles. Elsevier Composite Structures 77, 232-240.

[12] Karahan, M., 2008. Comparison of ballistic performance and energy absorption capabilities of woven and unidirectional aramid fabrics. Textile Research Journal, Vol.78, 718-730.

[13] Phoenix, S.L., Porwal, P.K., 2003. A New membrane model for the ballistic impact response and V50 performance of multi-ply fibrous systems. Elsevler International Journal of Solids and Structures, 40, 6723-6765.

[14] Tan, V.B.C., Ching, T.W., 2006. Computational simulation of fabric armor subjected to ballistic impacts. Elsevier International Journal of Impact Engineering 32, 1737-1751.

[15] Phoenix, S.L., Porwal, P.K., 2005. Modeling system effects in ballistic impact into multi-layered fibrous materials for soft body armor. Springer International Journal of Fracture, 135, 217-249. 